\title{
Promoting a Positive Affect: An Essential Adaptive Movement in Adolescents with Onco-haematologic Disease
}

\author{
Promover um Estado Disposicional Positivo: Um Movimento Adaptativo Essencial \\ em Adolescentes com Doença Onco-Hematológica \\ Promover un Estado Disposicional Positivo: Un Movimiento Adaptativo Esencial \\ en Adolescentes con Enfermedad Onco-Hematológica \\ Manuel Gonçalves Henriques Gameiro*; Manuel José Lopes**
}

\begin{abstract}
Theoretical framework: Some authors suggest the importance of positive constructs in the adaptation of adolescents with cancer. However, this component is understudied in the empirical literature.

Objectives: To make a comprehensive description of the conditions and strategies used by adolescents with oncohaematologic disease to promote a positive affect within the scope of an adaptive transition model.

Methodology: A qualitative methodology, namely Grounded Theory, was used. Data refer to the experiences of 23 adolescents with leukaemia or lymphoma.

Results: A substantive theory emerged, in which 3 adaptive movements are organised in a complementary and interactive way. In the efforts to promote and maintain a positive affect, specific strategies, from a hedonic and eudemonic perspective, are combined with the activation of affective relational resources and with the general strategies for coping with the illness. Conclusion: Promoting a positive affect is essential for the adaptation of adolescents with cancer, and should be valued by professionals and family members.
\end{abstract}

Keywords: Adolescents; leukemia; lymphoma; cancer; adaptation

\section{Resumo}

Enquadramento: Alguns autores sugerem a importância de construtos positivos na adaptação dos adolescentes com cancro. Contudo, esta componente é pouco desenvolvida na literatura empírica.

Objetivos: Fazer uma descrição compreensiva das condições e das estratégias utilizadas pelos adolescentes com doença onco-hematológica para promoverem um estado disposicional positivo, no quadro de um modelo de transição adaptativa.

Metodologia: Seguiu-se uma metodologia qualitativa, especificamente a Grounded Theory. Os dados referem-se às experiências de 23 adolescentes com leucemia ou linfoma. Resultados: Emergiu uma teoria substantiva, na qual 3 movimentos adaptativos se organizam de forma complementar e interativa. Nos esforços para promover e manter uma disposição positiva, estratégias específicas, no sentido hedónico e eudaimónico, combinam-se com a ativação dos recursos de suporte afetivo relacional e com as estratégias gerais de enfrentamento da situação de doença.

Conclusão: Promover um estado disposicional positivo é fundamental para a adaptação dos adolescentes com cancro, devendo ser valorizado pelos profissionais e familiares.

Palavras-chave: Adolescentes; leucemia; linfoma; cancro; adaptação

\footnotetext{
* MSc., Coordinating Professor, Nursing School of Coimbra, 3046-851, Coimbra, Portugal [mgameiro@esenfc.pt]. Contribution to the article: Conduction of the research; dat analysis; bibliographic search; article writing. Address for correspondence: Bairro Central, n. ${ }^{\circ}$ 3, Espírito Santo das Touregas, 3001-091, Coimbra, Portugal.

n* Ph.D., Coordinating Professor, Nursing School of São João de Deus, University of
** Pal Évora, 7000-811, Évora, Portugal. Contribution to the article: Supervision of the research; supervision of data analysis; article revision and writing.
}

\section{Resumen}

Marco contextual: Algunos autores sugieren la importancia de las construcciones positivas en la adaptación de los adolescentes con cáncer. Sin embargo, este componente está poco desarrollado en la literatura empírica.

Objetivos: Realizar una descripción comprensiva de las condiciones y las estrategias utilizadas por los adolescentes con enfermedad onco-hematológica para que promuevan un estado de disposición positivo en el contexto de un modelo de transición adaptativa.

Metodología: Se siguió una metodología cualitativa, concretamente, el muestreo teórico. Los datos se refieren a las experiencias de 23 adolescentes con leucemia o linfoma. Resultados: Surgió una teoría sustantiva, en la que 3 movimientos adaptativos se organizan de manera complementaria e interactiva. En los esfuerzos para promover y mantener una disposición positiva, las estrategias específicas, en el sentido hedónico y eudaimónico, se combinan con la activación de los recursos de apoyo afectivo relacional y con las estrategias generales de afrontar la situación de enfermedad.

Conclusión: Promover un estado de disposición positivo es esencial para que los adolescentes con cáncer se adapten, y debe ser valorado por los profesionales y los miembros de la familia.

Palabras clave: Adolescentes; leucemia; linfoma; cáncer; adaptación

Received for publication: 02.12 .14 Accepted for publication: 06.04 .15 


\section{Introduction}

The research results are consistent regarding the coping and resilience skills of adolescents with cancer. However, the classical models of coping, adaptation and adjustment do not seem to be enough to understand the experiences and the adaptive processes, which are considered in an integrated and detached way from predetermined models that somehow hamper data collection, analysis and interpretation (Gameiro, 2012).

This article focuses on the efforts of adolescents with oncohaematologic disease to promote and maintain a positive affect as an essential adaptive movement. It focuses on part of the results of a qualitative research study (Grounded Theory) carried out within the scope of the Ph.D. in Nursing entitled: Experiences and adaptive transition processes of adolescents with oncohaematologic disease during treatment (Experiências e processos de transição adaptativa dos adolescentes com doença onco-hematológica durante o tratamento).

Our particular drive for this study was scientific curiosity and the doubts resulting from our experience with these patients and their closest relatives and the lack of a satisfactory clarification from the literature review (Gameiro, 2012). This justifies the use of a qualitative approach, aimed more at discovery than at verification. The update of this research in reference databases, such as CINAHL and MEDLINE, did not add much of theoretical or empirical novelty.

The adaptive movement Efforts to promote and maintain a positive affect was discovered in the work of constant comparison inherent to the method of data analysis of the Grounded Theory.

The objective of this article is to make a comprehensive description of the conditions and strategies used by adolescents with oncohaematologic disease to promote a positive affect, within the scope of a databased adaptive transition model.

\section{Background}

In the literature, we highlight some studies on the importance of positive constructs in the adaptive processes of adolescents with cancer, such as optimism (Mannix, Feldman, \& Moody, 2009; Sulkers et al., 2013), the satisfaction with life (Enskär \& Essen,
2007), happiness (Bitsko, Stern, Dillon, Russell, \& Laver, 2008), a positive attitude towards life (Kingäs et al., 2001) and hope (Hinds, 2004; Juvakka \& Kylmä, 2009). However, this adaptive component is little integrated and underdeveloped in the studies related to processes of coping, adjustment and transition of people in highly stressful situations, as is the case for an oncologic disease and respective treatments, providing greater centrality to the reactive processes to deal with negative emotions (Greenglass \& Fiksenbaum, 2009; Khosla, 2006).

The literature on an association between a positive affect and coping with situations of stress is scarce. Nonetheless, there are some studies that establish this relationship with stress in general (Folkman \&, 2008; Khosla, 2006), specifically with proactive coping (Greenglass \& Fiksenbaum, 2009) or with resilience (Tugade \& Fredrickson, 2007).

\section{Research Question}

What are the characteristics of the adaptive movements and processes of adolescents with oncohaematologic disease during treatment?

\section{Methodology}

We used a qualitative research methodology, namely the Grounded Theory approach, close to the perspective of Corbin and Strauss (2008).

\section{Sampling}

The sample was composed of 27 accounts of the experiences of 23 adolescents (12-19 years) with leukaemia or lymphoma during treatment. It started with the collection of six accounts of adolescents with oncohaematologic disease posted on the websites of institutions of support to cancer patients (TEST. INT.) which were used, in a first stage, to increase the sensitivity of the researcher concerning the phenomenon under study. Then, through purposive sampling, six Narrative Interviews (NIs) were performed to patients in the maintenance phase or off treatment (maximum of 1 year). After the analysis of these interviews and online accounts, we continued sequentially with the collection of data by theoretical sampling, performing three Interviews to adolescents 
Focused in the Diagnostic Phase and the beginning of treatment (IFDPs) and seven Interviews Focused on Critical Situations throughout treatment (IFCSs), of which three were performed with parents and one together with the adolescent and the mother. Three Circumstantial Interviews (CIs) during hospitalisation were also performed collectively to adolescents and to one of the parents present. To these accounts, we added a blog of one of the adolescents interviewed and an email of another one as an alternative to the interview. The summary characteristics of the 23 adolescents are the following:

Table 1

Summary characteristics of sample participants

\begin{tabular}{ll}
\hline GendeR: & Female: $13 ;$ Male: 10 \\
Age: & $12-13$ years: $5 ; 14-16$ years: 14; 17-19 years: 4 \\
Diagnosis: & Leukaemia: 10 (ALL:5; AML:3; L??: 2); Lymphomas: 13 (HL:7; NHL:6) \\
\hline
\end{tabular}

\section{Data collection procedures}

The process of data collection was preceded by authorisations from two ethics committees and the formal authorisation from the directing board of the institution and the service responsible for the treatment of the interviewed adolescents. The informed consent was obtained from the adolescents and the parents, subscribed jointly with the researcher in a specific form approved by the ethics committees. All the interviewees were referenced by the oncology service of a paediatric hospital in the central region of Portugal, having been first contacted in person or by phone.

Guides were prepared for all interviews, but their application during the interview was flexible, since we explored the cues that emerged in the interviewees' discourse. With the exception of circumstantial interviews, all other interviews were carried out in the adolescents' homes. All interviews were audio recorded and transcribed for textual analysis. The interviews were conducted from May 2013 to July 2014 and lasted between 15 and 70 minutes, with the shorter interviews being those conducted during hospitalisation.

The online accounts were obtained in official websites of recognised organisations for support of patients with cancer.

\section{Data analysis}

A Qualitative Data Analysis (QDA) using NVIVO 8 was performed, following the method of questioning and systematic comparison, going through the phases of open coding and axial codification in order to identify, in an inductive way, the experiential structure and dynamics of the adaptive processes.

We started the analysis with open coding line by line, incident by incident, after the first four narrative interviews were held, moving on to the analysis of the previously obtained online accounts (previous overall reading of these accounts had been done to increase our sensitivity to the phenomenon under study). This first phase of analysis allowed the emergence of some categories related mainly to the experiences of the disease and treatment, emphasising the diagnostic phase and the beginning of treatment as a particularly critical period.

We conducted two more narrative interviews, trying to give more attention to adolescents' efforts and movements of coping and overcoming, as well as to the activation of the social and technical resources in critical moments and conditions. Data were analysed after their transcription and we felt the need to continue sampling focusing on the critical moments. At this time, several hypotheses of categorical organisations began to emerge that we continued exploring and successively reformulating and validating, from the perspective of axial analysis. We moved on with the interviews focused on the diagnostic phase and the beginning of treatment and then transcribed and analysed them. Following this analysis, we conducted the interviews focused on critical situations throughout treatment, in order to highlight other critical moments and conditions from the adaptive point of view and recurrent in the narratives of the adolescents with leukaemia and lymphoma and/or of their parents.

The data from the accidental interviews, the email and the blog were integrated in the analysis.

The analysis was based on a process of constant comparisons within and between data sources and within and between the categories that emerged, thus obtaining new insights on the adaptive experiences and their procedural dynamics. 
I: And the colleagues? Did they worry about you?

A: Yes. They came here to check on me whenever they could [Felt involvement and affection from the colleagues] They would rather not talk about it and so did I. [Not wanting to talk a lot about the disease: Focus not on the disease]

I: And the teachers?

A: The teachers. I never talked that much with them. My parents did [PARENTS AS InTERMEDIARY]. My class director went to see me at the hospital and another teacher went also there a lot of times to see me. [Felt INVOLVEMENT AND AFFECTiOn From the TEACHERS] [Positive EXPRESSION OF SELF-ESTEEM; RELATIONAL AND AFFECTIVE WELL-BEING]

I: Is there always insecurity? ...

A: Yes, but always positive thinking. [SHows the importance of Positive thinking: EFFort to PROMOTE A POSITIVE AfFect] Having strength [SHOWS THE IMPORTANCE OF INTERIOR STRENGTH] to... not to feel down. [TRiES TO CONTROL NEGATIVE FeELINGS]

I: How?

A: I dreamt a lot. Not to think about it. [ConTrolled the feelings; Dreamt (FanTasised): Focus not on the disease]

[AsSOCIATION BETWEEN THE CONTROL OF NEGATIVE EMOTIONS - GENERAL COPING STRATEGY - AND THE EFFORTS TO PROMOTE AND MAINTAIN A POSITIVE AFFECT]

I: What helped you believe that everything would turn out alright?

A: Enjoying life while we're alive and ... spending time with my friends [Enjoying life helps: Spending time with friends: Continue

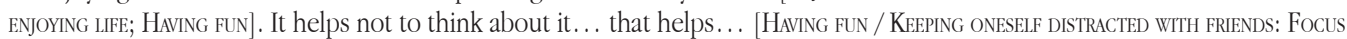
NOT ON THE DISEASE: HELPS]

[AsSOCIATION BETWEEN DISEASE ACCEPTANCE - GENERAL COPING STRATEGY - AND THE EFFORT TO PROMOTE AND MAINTAIN A POSITIVE AFFeCT]

(N16 M 14 HL, 2014)*

*(Source code_Adolescent gender_Adolescent age_Diagnosis_Interview date).

Figure 1. Example of the incident-by-incident coding and of the comparative analysis within an interview and between the analytical codes and categories under development.

Based on these constant comparisons and through an inductive process, the categories were being defined, refined and developed (saturating), from the most substantive (codes/concepts) to the most comprehensive and abstract ones, which include the former, such as the strategies of coping with the situation concerning each movement of adaptive transition. 
Table 2

Example of the inductive development of the categories regarding the strategies to promote and maintain a positive affect

\begin{tabular}{|c|c|c|c|}
\hline EXCERPTS OF ACCOUNTS (Examples) & $\begin{array}{l}\text { CODES / } \\
\text { CONCEPTS }\end{array}$ & $\begin{array}{l}\text { SUBCATEGORIES (Ac- } \\
\text { tions, Interactions, } \\
\text { Thoughts and Emotions) }\end{array}$ & $\begin{array}{l}\text { CATEGORIES } \\
\text { (Specific Strategies) }\end{array}$ \\
\hline $\begin{array}{l}\text { "Enjoying life while we're alive and... spending time } \\
\text { with my friends. It helps not to think about it ... and } \\
\text { that helps ..." (NI6_M_14_HL, 2014). }\end{array}$ & & & \multirow{2}{*}{$\begin{array}{l}\text { HAVING FUN, FEEL- } \\
\text { ING PLEASURE, AND } \\
\text { ENJOYING LIFE }\end{array}$} \\
\hline $\begin{array}{l}\text { "First I thought yes, that I would stay a bit away from } \\
\text { my friends, or so, but now I see that I didn't. We are } \\
\text { growing closer and closer, all of us. They always try } \\
\text { to cheer me up, and make me happy and I'm always } \\
\text { happy when I'm with them." } \\
\text { (IFDP3_M_14_ALL, 2014). }\end{array}$ & $\begin{array}{l}\text { Enjoying life by } \\
\text { socialising helps. } \\
\text { Spends time with } \\
\text { friends, happy. }\end{array}$ & $\begin{array}{l}\text { Being with significant } \\
\text { persons (socialising). }\end{array}$ & \\
\hline $\begin{array}{l}\text { "It's the prom... of this school year. It's usually this } \\
\text { time around. I enjoy going." (EN4_M_15_ALL, 2014). }\end{array}$ & $\begin{array}{l}\text { Likes to participate } \\
\text { in the school's } \\
\text { prom party. Recog- }\end{array}$ & $\begin{array}{l}\text { Going to parties / Cel- } \\
\text { ebrating. }\end{array}$ & \multirow{5}{*}{$\begin{array}{l}\text { KEEPING RELEVANT } \\
\text { PROJECTS, ACTIVI- } \\
\text { TIES AND ROLES }\end{array}$} \\
\hline $\begin{array}{l}\text { "Practice some light sports, when possible, continue } \\
\text { going out ... all of this makes us happier and stronger, } \\
\text { I'm sure." (BLOGUE_M_14_HL, 2013). }\end{array}$ & $\begin{array}{l}\text { nises the positive } \\
\text { effects of sports. } \\
\text { The parents }\end{array}$ & $\begin{array}{l}\text { Keeping personally rel- } \\
\text { evant activities and roles, } \\
\text { namely sports activities, }\end{array}$ & \\
\hline $\begin{array}{l}\text { "FATHER: He plays. He can play now. He just can't } \\
\text { Swim... because ... because of the catheter. } \\
\text { MOTHER: This week he's not going to train, he's } \\
\text { very weak... He trains on Tuesdays and Fridays, he }\end{array}$ & $\begin{array}{l}\text { recognise the } \\
\text { importance for } \\
\text { the adolescent of } \\
\text { getting back to } \\
\text { training. }\end{array}$ & $\begin{array}{l}\text { activities in associations, } \\
\text { the school and within the } \\
\text { family. }\end{array}$ & \\
\hline $\begin{array}{l}\text { can spend a whole week without training, but..." } \\
\text { (IFCS4_M_14_AML_PARENTS, 2014). }\end{array}$ & $\begin{array}{l}\text { The adolescent } \\
\text { has projects for } \\
\text { the future. }\end{array}$ & $\begin{array}{l}\text { Keeping important proj- } \\
\text { ects active. }\end{array}$ & \\
\hline $\begin{array}{l}\text { "I have, a lot of them. I want to work as beautician, } \\
\text { I want to get my driver's licence and buy a car... I } \\
\text { want to get married and have children... God will- } \\
\text { ing..." (ECI3_F_16_NHL, 2014). } \\
\text { "After this, I want to get the heavy vehicle licence and } \\
\text { become a firefighter." (IFCS1_M_17_NHL_FATHER, } \\
\text { 2014). }\end{array}$ & & & \\
\hline
\end{tabular}

\section{Results}

In this article, we focus particularly on one of three adaptive movements that we inferred from data: Adaptive efforts to promote and maintain a positive affect. However, we will start with an overall presentation of these movements, so as to facilitate a more integrated understanding.

\section{Adaptive movements of adolescents with oncohaematologic disease during treatment} Throughout the disease and treatment, adolescents develop a set of adaptive processes according to different determinants which correspond to internal or external changes that require adjustment and coping efforts. These efforts, although they are always personal and circumstantial, are necessarily influenced by the social-affective and technical resources that, in an interactive way, encourage (or inhibit) and complement them.

The experiences and adaptive processes are always conditioned by the evolution of the disease, by more difficult or relief phases and often by dramatic moments of disruption, increasing feelings of vulnerability and uncertainty. In this context, parents are a leading social resource, despite the fact that they also experience situations of stress and adjustment, which interrelate with (and condition) the experiences and adaptive processes of adolescents.

From the analysis of the accounts, three key adaptive movements emerged: a) Efforts of self-regulation and adjustment to the disease situation; b) Efforts to 
promote and maintain a positive affect and c) Efforts to deal with referential situations of suffering (Figure 2). The first focuses on complacency and coping with the disease situation in general, the second is determined by the need for emotional well-being and satisfaction with life, and the third is organised so as to deal with critical situations of suffering. These movements are complementary and mutually reinforcing, in the sense of adaptive responses that emerge during treatment and in the medium-term (after treatment).

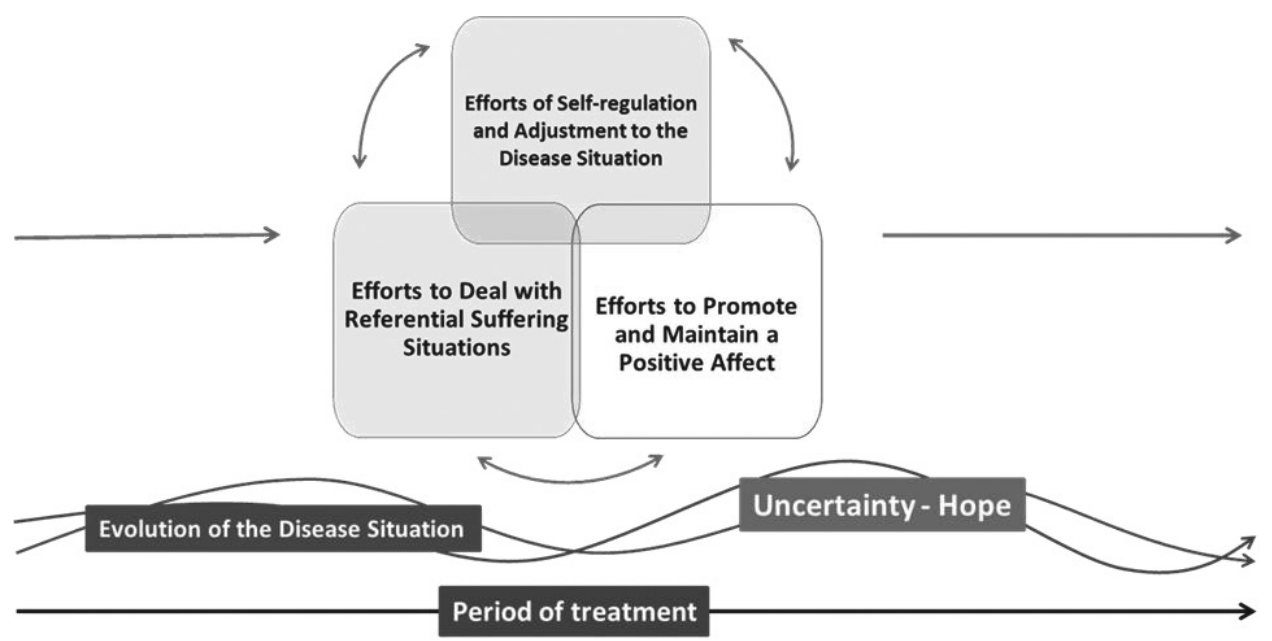

Figure 2. Adaptive movements of adolescents with oncohaematologic disease during treatment.

\section{Adaptive efforts to promote and maintain a positive affect}

This movement emerges as essential in the adaptive transition process of adolescents with oncohaematologic disease during the phase of treatment (Figure 2).

\section{Conditions}

This is an active process of search for opportunities and conditions to enjoy life from a hedonic and eudaimonic perspective (feel good, obtain pleasure, experience joy and sense of normality and value of life) and not, as it might seem at first sight, a reaction against a negative affective-emotional state (of anxiety, depression, psychological distress or lack of inner strength).

"Enjoying life while we're alive and... spending time with my friends. It helps not to think about it ... and that helps ..." (NI6_M_14_HL, 2014).

It is also not a basic way of escaping or denying the problems, but rather the satisfaction of the need felt by any individual to live life with pleasure, feeling happy and excited to face the existential difficulties of everyday life. In adolescents, this need is more urgent, because at this stage of life the need to spend time with their peers, share adventures and sensations, go to parties, make new discoveries, experience new sensations, and feel satisfied with life is considered essential, from a developmental perspective, to achieve autonomy and increase their social-affective network.

"The need is to go out and hang out with our friends and all of this. And being at the hospital, alone, not being able to be with friends or anyone is a bit more complicated." (IFCS2_M_14_AML, 2014).

In these patients, it is particularly important to maintain hope in a cure and a positive mood to continue the fight.

However, these conditions that determine the search for positive emotions and feelings do not translate directly into effective adaptive processes. They are mediated by the emotional-motivational state that derives from certain intervening conditions, among which are the experiences associated with the disease and treatments, in particular the discomfort, pain and suffering related to specific situations, as well as by psycho-emotional pressure derived from personal perception of the disease and the informational anticipation of procedures and possible outcomes.

Other intervening conditions in this process are the personality, internal resources and emotional security of adolescents, as well as the more or less 
favourable socio-relational environment. In addition, this movement towards the promotion of a positive affect is also more directly affected by the available resources for relational support and, in particular cases, the psychotherapeutic resources that need to be activated to encourage and sustain the adaptive efforts of adolescents.

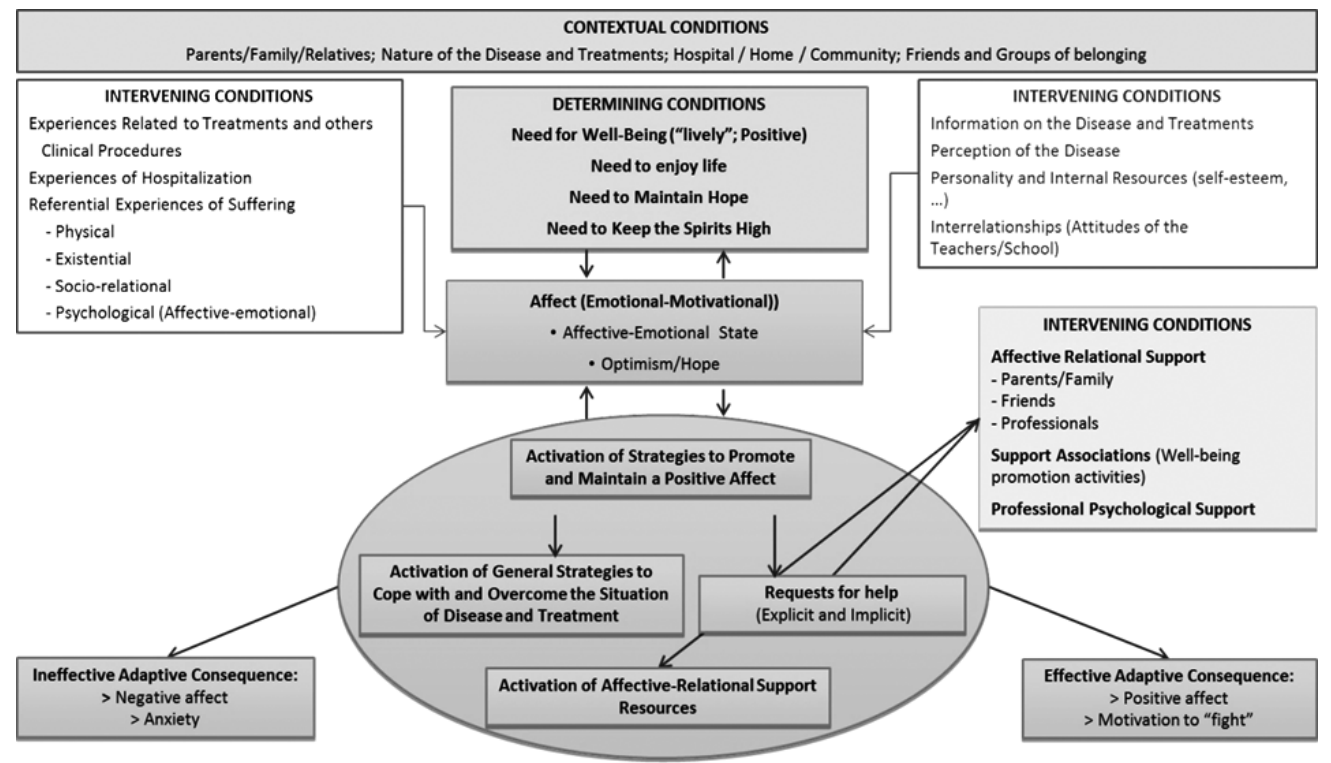

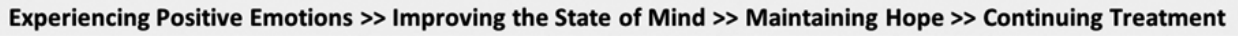

Figure 3. Adaptive efforts to promote and maintain a positive affect.

\section{Strategies}

This movement inevitably involves the activation of general strategies of coping and overcoming of the situation of disease and treatment, especially those related to the control of negative emotions (Focus not on the disease; Acquisition of the sense of security and control; Preservation of a positive self-concept, Resignation/acceptance of the disease and treatment), because the ability to enjoy life and have pleasure presupposes the moderation of these emotions.

Another important aspect is the activation of social resources, with special focus on interpersonal relationships with the family, friends and professionals, who, with their special attention (care), are the primary source of pleasure, but, through their example, incentive and openness, can also promote the experience of activities for personal fulfilment and pleasure.

However, in this article, we intend to highlight the activation of specific strategies to promote and maintain a positive affect and continue to enjoy life. Certainly not exhausting the possibilities, the strategies that have emerged in these accounts (Table 3) translate into certain actions, interactions, emotions and thoughts (HOW) that develop inside the individuals and in the social relationships in favourable moments (WHEN). 
Table 3

Specific strategies to promote and maintain a positive affect

\begin{tabular}{|c|c|c|}
\hline CATEGORIES & WHAT & WHEN \\
\hline $\begin{array}{l}\text { HAVING FUN, FEELING } \\
\text { PLEASURE AND ENJOY- } \\
\text { ING LIFE }\end{array}$ & $\begin{array}{l}\text { Getting involved in hedonic } \\
\text { activities, i.e. activities that } \\
\text { lead to pleasure and well- } \\
\text {-being. }\end{array}$ & $\begin{array}{l}\text { Throughout the treatment } \\
\text { process. Particularly out } \\
\text { of critical moments and of } \\
\text { "Focus on the disease". }\end{array}$ \\
\hline
\end{tabular}

HOW

Being with significant others (Socialis-

ing).

"Going out".

Going to parties / Celebrating.

Listening to music.

Being pampered.

-being.

Returning home and enjoying the comfort at home.

Having fun (Playing games, watching

TV, joyful activities ...).

Feeling of maintaining (or reacquiring) conditions to

MAINTAINING / REACQUIRING THE SENSE OF NORMALITY IN LIFE

\section{KEEPING RELEVANT PROJECTS, ACTIVITIES AND ROLES}

ATTACHING POSITIVE MEANINGS TO COMMON THINGS AND EVENTS

THINKING POSITIVE AND CONTROLLING NEGATIVE EMOTIONS

POSITIVELY REVALUING ASPECTS OF LIFE OR THE SITUATION perform the daily activities as before the disease and being able to accomplish life projects.

Feelings of well-being, autonomy and conformity.

Maintaining the contact with groups of belonging and the investment in relevant projects and roles (even if conditional).

Positive valuation of common facts and events, thus obtaining pleasure and meaning of life.

Valuation of emotional well-being and capacity for positive feelings. Maintenance of a positive and excited state of mind.

Attachment of special meaning to the situations of possibility of continuing "to live life".
More present in the final stage of treatment, particularly outside of hospitalisation settings.

Throughout the treatment process, particularly when out of critical situations, or situations of major limitation or constraints.

More effective outside critical moments of the disease and treatments. Particularly active in the final phase of treatments.

Feeling that there are conditions (namely medical permission) to continue the interrupted activities and roles.

Feeling well and autonomous to perform the daily activities.

Making a conformity assessment of itself with its conditions.

Feeling that there are conditions to continue with relevant life projects.

Maintaining personally relevant activities and roles, namely sports activities, activities in associations, in the school and within the family.

(The maintenance of these activities may be restricted and adapted to the possibilities of the adolescents. As regards school activities, they can be maintained with the support of teachers from the hospital).

Maintaining active important projects.

Highlighting the pleasant feelings (socialising, eating, going out, going for a walk, partying, ...).

Highlighting the pleasure related to common events and activities. Discovering new pleasant sensations.

Highlighting expressions of care or compliments.

Valuing positive thinking and positive emotional state

Throughout the treatment Avoiding thinking about and/or talking about negative issues. Imagining positive emotional experiences.

Talking about positive issues.

Attaching more value to the activities Throughout the treatment and roles that can be performed. process. Attaching more value to the presence of and relationship with other people. 


\section{MAINTAINING AND EXPRESSING POSITIVE MOOD}

ATTACHING MEANING THROUGH SPIRITUAL BELIEFS

SOCIALISING - SHARING

VALUING RELATIONAL AND AFFECTIVE WELLBEING

INVESTING IN A POSITIVE SELF-CONCEPT

\section{VALUING GAINS AND BENEFITS OF THE SITU- ATION}

REFORMULATING AND ADJUSTING LIFE OBJECTIVES AND PRIORITIES
Maintenance of the capacity to consider cosmic aspects in the life circumstances (including disease) and continue to laugh and smile.

Believing that the disease is a divine plan, a way of putting oneself to test and improving oneself.

Maintenance of social contact and positive communication not focused on the disease.

Valuing manifestations of affection and emotional well-being, particularly within the family, but also in the hospital and other interaction sites.

Maintenance of a positive self-concept, particularly in relation to self-efficacy, selfimage and self-esteem.

Positive reinterpretation: Identification of some gains and benefits facilitated by the situation of being ill.

Redefining the meanings of life and restructuring the values taking into account the demands of the situation and the limitations.
Valued in the treatment phase, after the critical phase of diagnosis and beginning of treatment.

Throughout the treatment process.

Throughout the treatment process.

Maintaining humour sensitivity and the capacity to laugh.

Expressing happiness through smile/

laugh.

Laughing of life incidents, even those related to the disease or the treatments.

Believing that the disease is fate and proof of divine.

Believing in a strength from within or the divine.

Believing in divine kindness.

Sharing activities and having fun with others with a positive attitude and avoiding talking about the disease. Establishing relationships and developing activities with other patients.

Throughout the treatment Valuing manifestations of affection. process. Appreciating the positive relational environment.

Believing in the personal capacity to overcome the situation (perceived

Throughout the treatment self-efficacy).

process. Feeling responsible.

Taking care of one's personal image.

Valuing compliments

Valuing the gains and benefits resulting from the situation.

Throughout the treatment Valuing promises and rewards. process. Taking advantage of the opportunity and investing in fulfilling the dreams. Relativizing the losses.

Finding a meaning in life in the fight

Throughout the treatment against the disease.

process, after the critical Becoming aware of the limitations and phase of diagnosis and adjusting priorities.

beginning of treatment. Revaluing possible reasons for investment (e.g., school)
As shown in the table, these strategies are organised, on the one hand, to lead to pleasure and savouring and, on the other hand, to facilitate the readjustment of personal values and the (re)acquisition of meanings and purposes in life.

\section{Consequences}

What is expected of this adaptive motion of adolescents with oncohaematologic disease is, in very simple terms, the experience of positive emotions and the promotion of a positive and hopeful state of mind, which is essential in a situation of serious illness to build resilience to the hardships of the disease and the need to continue the treatments.

"Always highly optimistic .... It seems impossible. How did he... it was not easy. I never heard my son ...I never heard him say: I'm completely fed up with this. I never heard him say that." (ESFC2 M 14_AML FATHER, 2014).

This positive affect may be experienced through activities of pleasure and joy, a positive perception of the self and the resources, a relational well-being, a sense of normality and conformity, a positive meaning in life and reasons for living and, obviously, the relief of emotional tension.

"I wanted to fight and I did everything to be as cheered up as possible and to ensure that everything would end quickly. I wanted so much to go back to school and do my normal life." (TEST. INT._F_12_L??, 2013).

"The main thing is having the support from others, learning to appreciate what really matters, moving 
forward and NEVER abandoning treatment, even in difficult times." (BLOGUE_M_14_HL, 2013).

"Listening to music. It's something that helps me a lot." (EFSC4_F_16_HL, 2014).

\section{Discussion}

During treatment, adolescents with leukaemia or lymphoma understandably use different strategies to promote a positive affect. These strategies are organised in a specific adaptive movement, and they are combined with general strategies to cope with and overcome the situation of disease and with the activation of relational resources, with both negative and positive emotions co-occurring, as argued by Folkman (2008).

The strategies used to promote a positive affect, on the one hand, contribute to the satisfaction of the need of adolescents in general to feel happy and motivated, giving meaning to their lives and feeling able to respond to the challenges of the environment and to develop themselves positively (Larson, 2000) and, on the other, competing for the maintenance of the mental and physical well-being, they have an important adaptive function in difficult periods (Folkman, 2008).

Thus, the adaptive movement focused on the promotion of a positive effect works together with the efforts of self-regulation and adjustment to the situation of disease and with the adaptive efforts in conditions of referential suffering, in the nuclear dynamics of the adaptive transition processes of adolescents with oncohaematologic disease during treatment.

The three movements are interactively related, reinforcing each other. From this perspective, Tugade and Fredrickson (2007) refer to emotional regulation processes through which individuals, when they feel down, tend to search for activities that improve their state of mind and make them feel better (watch a comedy, go for a walk, hang out with friends). In the study of Greenglass and Fiksenbaum (2009), with adults in stressful situations, the authors concluded that a positive affect promotes proactive coping.

Folkman (2008) attaches particular emphasis to meaning-focused coping strategies, but, although these strategies also stand out in the study findings, other methods used by adolescents to achieve positive emotions are highlighted, especially those related with experiences of fun and pleasure or with the maintenance of relevant projects, activities and roles. This is also in line with the recommendations of Tugade and Fredrickson (2007), who also value hedonic experiences. Adolescents also value socialisation with positive individuals and the expression of positive mood, for example, through laughter and smile. This strategy to increase laughter and smile is underlined by the abovementioned authors, who cite studies that highlight the positive impact of these expressive behaviours on emotional functioning, even when they differ from the inner experience.

Referring in particular to stressful situations, Khosla (2006) and Fredrickson $(1998 ; 2001)$ underline the importance of a positive affect, considering that it extends the repertoires of thought-action. By making thoughts more flexible, creative and integrative, a state of positivity helps to process emotional information and facilitates the development of more effective responses to problems. Furthermore, in situations of persistent emotional pressure, in which resources start to run out, the positive experiences correspond to a truce or a relief, thus enabling for the recovery of strength and the maintenance of coping efforts (Fredrickson, 1998; 2001).

As regards the importance of positive emotions in stressful situations, another reason should be considered which has to do with the protection against neuroendocrine, cardiovascular and immunological maladaptive responses, increasing biological defences (Dockray \& Steptoe, 2010; Steptoe, Wardle, \& Marmot, 2005).

\section{Conclusion}

By acknowledging the relevance of the positive affect for the development of a proactive coping with the situation of disease, for the control of negative emotions and for the increase of the biological resistance of individuals, health professionals and family members should provide opportunities and facilitate the conditions for adolescents with cancer to develop, as much as possible, effective strategies for their promotion.

The activation of relational resources is essential, thus creating an environment of attention and 
involvement around adolescents with cancer, taking into account their needs and wishes, expressing good mood, hope and enthusiasm and encouraging and supporting decisions, activities and projects of personal relevance.

Within this scope, recreational spaces and associations of friends of patients also play an important role, namely because they provide conditions for playful activities (inside and outside the hospital), organise boot camps that promote sharing activities between young people or facilitate relevant life experiences and the fulfilment of dreams and goals (meetings, trips, adventures, ...).

\section{References}

Bitsko, M. J., Stern, M., Dillon, R., Russell, E. C., \& Laver, J. (2008). Hapiness and time perspective as potencial mediadores of quality of life and depression in adolescent cancer. Pediatric Blood Cancer, 50(3), 613-619.

Corbin, J., \& Strauss, A. (2008). Basics of qualitative research: Techniques and procedures for developing grounded theory ( $3^{\mathrm{a}}$ ed.). USA, Washington D.C: SAGE Publications.

Dockray, S., \& Steptoe, A. (2010). Positive affect and psychobiological processes. Neuroscience and Biobehavioral Reviews, 35(1), 69-75.

Enskär, K., \& Essen, L. V. (2007). Prevalence of aspects of distress, coping suport and care among adolescents and young adults undergoing and being off cancer treatment. European Journal of Oncology Nursing, 11(5), 400-408.

Folkman, S. (2008). The case for the positive emotions in the stress process. Anxiety, Stress \& Coping, 21(1), 3-14.

Fredrickson, B. L. (1998). What good are positive emotions. Review of General Psychology, 2(3), 300-319.

Fredrickson, B. L. (2001). The role of positive emotions in positive psychology: The broaden-and-build theory of positive emotions. American Psychologist, S6, 218-226.
Gameiro, M. G. (2012). Adaptação dos adolescentes com cancro na fase de tratamento: Uma revisão da literatura. Revista de Enfermagem Referência, 3(8), 135-146.

Greenglass, E. R., \& Fiksenbaum, L. (2009). Proative coping, positive affect and well-being. European Psychologist, 14(1), 29-39.

Hinds, P. S. (2004). The hopes and wishes of adolescents with cancer and the nursing care that helps. Oncology Nursing Forum, 31(5), 927-934.

Juvakka, T., \& Kylmä, J. (2009). Hope in adolescents with cancer. European Journal of Oncology Nursing, 13(3), 193-199.

Khosla, M. (2006). Positive affects and coping with stress. Journal of the Indian Academy of Applied Psychology, 32(3), 185192.

Kingäs, H., Mikkonen, R., Nousiainen, E.-M., Rytilahti, M., Seppänen, P., Vaattovaara, R., \& Jämsä, T. (2001). Coping with the onset of cancer: Coping strategies and resources of young people with cancer. European Journal of Cancer Care, 10(1), 6-11.

Larson, R. (2000). Toward a psychology of positive youth development. American Psychologist, 55(1), 170-183.

Mannix, M., Feldman, J. M., \& Moody, K. (2009). Optimism and health-related quality of life in adolescents with cancer. Child: Care, Health and Development, 35(4), 482-488.

Steptoe, A., Wardle, J., \& Marmot, M. (2005). Positive affect and health-related neuroendocrine, cardiovascular, and inflammatory processes. PNAS, 102(18), 6508-6512.

Sulkers, E., Fleer, J., Brinksma, A., Roodbol, P. F., Kamps, W. A., Tissing, W. J. \& Sanderman, R. (2013). Dispositional optimism in adolescents with cancer: Differential associations of optimism and pessimism with positive and negative aspects of well-being. British Journal of Health Psychology, (18), 474-489.

Tugade, M. M., \& Fredrickson, B. L. (2007). Regulation of positive emotions: Emotion regulation strategies that promote resilience. Journal of Happiness Studies, 8, 311-333. 
